Leach, Tony ORCID:

https://orcid.org/0000-0002-1021-6361 (2012) Researching graduates' lived experiences of vocational learning. Research in Post-Compulsory Education, 17 (2). pp. 261-275.

Downloaded from: http://ray.yorksj.ac.uk/id/eprint/486/

The version presented here may differ from the published version or version of record. If you intend to cite from the work you are advised to consult the publisher's version: http://dx.doi.org/10.1080/13596748.2012.673919

Research at York St John (RaY) is an institutional repository. It supports the principles of open access by making the research outputs of the University available in digital form. Copyright of the items stored in RaY reside with the authors and/or other copyright owners. Users may access full text items free of charge, and may download a copy for private study or non-commercial research. For further reuse terms, see licence terms governing individual outputs. Institutional Repository Policy Statement

\title{
RaY
}

Research at the University of York St John

For more information please contact RaY at ray@yorksj.ac.uk 


\title{
Researching graduates' lived experiences of vocational learning
}

\author{
Tony Leach
}

Faculty of Education and Theology, York St John University, York, UK

Email: t.leach@yorksj.ac.uk

\section{Researching graduates' lived experiences of vocational learning}

The aim of this paper is to exemplify the value of using a phenomenological approach when investigating graduates' lived experiences of vocational learning. For this study, qualitative data was obtained during a series of email interviews with 35 participants. As a group they are highly aspirational and, during their graduate studies, were employed as teaching or higher level teaching assistants in schools. The importance of this group lies in their potential contribution to the wider, international discourse concerning vocational learning and graduate employability. The research underlines the extent to which organisations are 'sites of struggle' wherein opportunities for vocational learning arise as part of people's everyday collective work, and when 'acting up' an absent person's role. Likened to a 'lived' apprenticeship in participant narratives, vocational learning is seen to be negotiated within, and at, the boundaries of working groups, and played out through the dynamics of human relations.

Keywords: Vocational learning; communities of practice; 'lived' apprenticeship; job demand/job control; psychological contract; managing change; phenomenological perspective

\section{Background to the research}

The roots of lifelong learning concept can be traced back to the adult education movement during the early twentieth century, when education was first conceived as a 'lifelong process' and said to be based on a 'learner's living textbook' (Lindeman 1926). Referring to those times, Centeno $(2011,136)$ records how 'education across the lifespan was initially an educational and 
pedagogical conception aimed at adults' whose learning was said to take place outside the institutionalised school system.

In the 1920s and early 1930s few predicted the emerging prominence of the idea that participation in lifelong learning is an essential requirement if nations and their people are to achieve economic growth and social cohesion, within modern-day national and international policy contexts. (Boeren et al., 2010, 45). Nor was the linking of institutionalised postcompulsory education with lifelong learning anticipated. Nowadays, in the new economic climate there is an expectation that educational establishments will transform the human being into an employable resource, equipped with the knowledge and skills for employment (BIS 2009a). The origins of this expectation lie within a dominant instrumental, consumerist perspective concerning the role and purpose of education. According to this perspective, the human being is someone who emerges into an entrepreneurial, assertive, independent and selfsufficient person, capable of and willing to engage in lifelong learning as means of managing his, or her, career in an ever-changing economically determined context (Brooks and Everett 2008, 240; Clarke and Patrickson 2008, 122). It is assumed there is a linear relationship between education and work, and that employers will be able to match their requirements to measured graduate attainment in subject knowledge and key skills (Holden and Hamblett 2007, 517). There is also an expectation that research and knowledge exchange will primarily be from education to the workplace (BIS 2009b; Guile 2009, 762-3; Hodkinson 2005, 522).

Questioning these taken-for-granted assumptions, Guile (2009, 761-4), claims they disregard fundamental changes within national and global markets over recent decades, and the social nature of knowledge creation and deployment within organisations. There was a time in the 1960s and 1970s when it was widely assumed change could be managed incrementally. Nowadays, accounts of life within organisations describe how people are confronted by rapid and continuous change which can be transformational in the way it affects individuals and organisations (Hayes 2007, 11-13; Stoll and Seashore 2007; Starkey 1996). In such circumstances, it is said people often operate at the outer limits of their own and other people's experience, and how they are required to make decisions based on insufficient information, and how decisions taken in response to one set of needs often result in undesired and challenging consequences in other areas of the organisation (Edwards et al., 2010, 28-9; Kanter 1996, 44-5; Stata 1996, 318-19).

In these labour market conditions there is a growing expectation among employers that job applicants will already have some 'hands-on' experience of working alongside professionals in the field, and will be familiar with normal everyday practices in the sector. Guile (2009, 762-3) 
highlights the emergence of a post-degree vocational need resulting in new graduates undertaking unpaid internships and work placements that enable them to gain and demonstrate the necessary contextual knowledge and skill, and to join networks through which they can build employment capital.

These developments have far-reaching implications. Increasingly, the workplace is seen to be the site of learning and knowledge creation, undermining assumptions concerning the dominance of universities in the creation of the intellectual capital necessary for organisational and economic transformation (Nixon et al. 2006, 10). Moreover, viewed through the lens of situated learning theory (Lave and Wenger 1991), some writers claim institutions of further and higher education are bounded systems wherein learning is influenced by the context, knowledge systems and practices of the sector which encourage students to learn how to be students. This is quite different, it is argued, to learning in everyday life and in other sectors (Berner 2010, 27-28; Leach 2010; Hodkinson 2005).

\section{The individual and the organisation}

The reciprocal influence of the individual and the organisation on each other is widely discussed in the literature, and particularly within the context of the working group. The working group and its importance in the working lives of most people are well researched (Katzenback and Smith 1993; Hayes 1998a \& 1998b; Wenger 1998). Interactions within working groups are said to be the primary source of people's learning experiences, social practice, meaning systems and identity (Lave and Wenger 1991; Wenger 1998). To document these social interactions, and their outcomes, is to document the ongoing social processes of knowledge creation.

According to Lave and Wenger (1991), Wenger (1998) and Wenger et al. (2009), social participation is a process of learning. People acquire and use knowledge when engaging with one another to pursue shared identity driven goals. Developing this theory of learning through engagement in 'communities of practice', Wenger suggests organisations can usefully be construed as constellations of informal communities of practice, formed by people who come together to create a practice to get jobs done. He argues that, when engaging with one another in this way, and in the course of learning how to meet employer and client expectations, people achieve a number of outcomes. Firstly, they create their own reified practices, routines, rituals, artifacts, symbols, conventions, stories and histories, and, develop and preserve a sense of identity. Secondly, they assign meanings - a way of talking about their changing experiences and abilities, and to explain the way things are in their immediate environment and the world at large. Thirdly, they develop practice, i.e. personal and shared competence to do what needs to be 
done. Fourthly, they create a sense of community, a way of talking about the social configurations in which they engage. Finally, they create a sense of identity, a way of talking about personal and shared histories - notions of who they are, and how they 'fit' within the community of informal communities (Wenger 1998).

The power of this theory of informal communities of practice lies in the way it highlights the importance of the relationship between social participation and learning within the workplace. However, Lave and Wenger are silent on the substantive issues of power and its expression, and on the existence and impact of conflicting individual ideologies within organisations. It is assumed people choose to join and participate in information communities of practice. There is no apparent attempt to acknowledge the possibility, or take account, of competing personal visions, conflicts of interest, dysfunctional learning or industrial unrest. Given the enormous challenges which individuals and organisations now face as cuts in funding are introduced, we have to reconsider the individual-organisation bond. The question then is: how can we conceptualise the individual-organisation bond in a way which generates new opportunities for study and intervention in this new age of austerity and corresponding changes in the employment landscape?

\section{Methodological Background}

There is an ongoing debate within the research community about epistemologies, that is, theories concerning the way scientific knowledge is acquired, and judged to be valid. Sometimes characterised as a 'realist' - 'anti-realist' dialogue, the debate is between those who subscribe to the view that the variables of people's everyday lives are inherently 'real' and can be identified, measured and sometimes manipulated using scientific methods in controlled situations, and those who claim personal and collective knowledge are, in part at least, constructed during everyday social interactions (Edley 2001; Fox 1997; Gergen 2001a, 2001b; Hayes 1997). According to this constructivist perspective, knowledge is subjective and dynamic and exists in the understandings, and meanings, which people ascribe to their experiences when interacting with one another in social-historical settings.

The roots of the constructivist perspective can be traced back to the influential work of Berger and Luckmann (1966), who argued that beliefs about reality are created during social interactions; that social institutions and people's perceptions of one another are created during social interaction; and that beliefs about reality, which are constructed during social interaction, play an important role in the (re)construction of institutions, and people's knowledge of one another. In other words, according to Berger and Luckmann, people's knowledge of the world is 
the product of their own perceptions and understandings, i.e. the results of personal sensemaking over time. People are said to assign meanings to their experiences within social settings, and to respond to those experiences in ways which can subsequently be explained in terms of those assigned meanings.

\section{Husserl and transcendental phenomenology}

According to Lemon and Taylor (1997, 239), 'Phenomenological research seeks to ask two related questions: what is the phenomenon that is lived and how does it express itself'. Located firmly within the constructivist side of the debate, phenomenology is both a philosophical approach to our understanding of the world, and also a way of gathering information about it. The origins of this approach are generally attributed to ideas originally developed by Edmund Husserl and, subsequently, Martin Heidegger. In his writings, Husserl is highly critical of a perceived preoccupation among theorists with the use of quantitative methods to test hypotheses about phenomena because, in his view, they fail to take account of actual human experience. The notion of phenomena being independent of human sense-making which we can investigate using scientific methods is challenged from a phenomenological viewpoint. Instead, phenomenologists focus their attention on the perceptions of people concerning their experiences and the meanings they ascribe to them, their attitudes and beliefs and their feelings and emotions in the light of those experiences. Viewed through the lens of 'transcendental' phenomenology (Husserl 1931), truth and facts do not exist outside us waiting to be discovered, the social world exists only through the way it is experienced and interpreted by people, including researchers (Lemon and Taylor 1997, 229). Meanings which we attach to our lived experiences in the world and perceptions concerning them are social creations. They emerge only within specific historical situations and can be interpreted only in terms of the meaningful ways in which they are experienced, made sense of and enacted in everyday life. Moreover, according to this perspective, there is the distinct possibility of people and groups of people seeing thing differently at different times and in different circumstances, and them creating personal, shared and sometimes competing perceptions of reality when interacting with one another (Denscombe 2008, 79).

The 'transcendental' phenomenological approach advocated by Husserl (1931) aims to uncover the underlying fundamental aspects, the transcendental essence of human experience. Using this approach, the researcher's task is to try to penetrate as deeply as possible the participant's internal, personal world, and to try to understand their experiences as completely as possible (Hayes 2000 188). Consequently, to accomplish this, Husserl (1982) developed a process comprising a number of steps which the phenomenologist can use as a means of 
eliminating all preconceptions regarding the experienced phenomena (Hayes 2000, 189-190). The first step is to reflect on and acknowledge his, or her, prior knowledge, presuppositions and biases concerning the phenomenon, and to put them to one side so that the analysis can uncover the meanings of the phenomenon from the participant's perceptive. This process is called bracketing, and when working in this way, it is not possible to be totally free of bias. However, consciously bringing to the surface and acknowledging one's prior knowledge and presuppositions does mean the researcher can take steps to control its influence.

The second stage involves decisions over which experiences should be the focus of attention and included in the study, and which methods to use when structuring the participant's experiences and recording them. This is why the earlier process of bracketing is so important. The insights and understandings gained during that early stage are necessary when decisions are taken about the continued direction and structure of the research. For example, becoming aware of the importance of a particular part of the experience of employment as described by participants may result in the researcher deciding to focus on that aspect of the participant's experience.

The third stage of the analysis is about intuiting which involves the researcher deciding on and adopting a particular mental approach when interacting with the data. Putting to one side previous assumptions and beliefs, the researcher sets out to explore the phenomenon in as openminded way as possible. Commenting on this process, Hayes $(2000,190)$ suggests it is about acknowledging the importance of the participant's subjective experience which cannot be understood from the outside, and, therefore, investigated using objective means. The phenomenologist's stance is that these experiences can only be uncovered and appreciated as far as possible when using a combination of intuition, empathy, imagination and open-mindedness (Hayes 2000, 190). The process of reading and re-reading interview transcripts is an iterative one. Over time, the aim is to develop a sense of understanding of the person's point of view.

In the final stage of the analysis, and working in a way similar to the one used by an ethnographer, the phenomenologist uses the participant's descriptions of the experiences in such a way that that they are drawn together to make intuitive sense to other people. This is a way of testing whether the researcher's descriptive insights concerning the meanings people ascribe to their experiences are appropriate or not. Another test is to check with the respondents to see whether, or not, they feel the account of their experiences is valid, or not.

In phenomenological research there are internal and external tests of validity. Internal validity involves comparing the researcher's account of the participant's experiences with what the participants have said during the interviews, to see whether they match, or not. External 
validity is achieved when the research participant considers whether, or not, the researcher's final account of their lived-experiences is a true reflection of how they see things. Obtaining the participant's subjective agreement concerning the validity of the account is entirely consistent with the principles of phenomenological research (Hayes 2000, 191).

\section{Heidegger and hermeneutic phenomenology}

Although different in a number of ways, the traditions of 'transcendental phenomenology' and 'hermeneutic phenomenology' (Heidegger 1962) share the same concern with investigating the essence of human experience. However, advocating a hermeneutic approach in phenomenological research, Heidegger opposed the idea of bracketing as a means of uncovering true knowledge on the grounds of our already 'being in the world' and that meaning is 'not some stable essence that is mediated by interpretation' (Heidegger 1962). Instead, he argued that meaning resides in a holistic web of lived experiences of phenomena, that is, historical learned practices and understandings which we each create over time when interacting with and making sense of certain aspects of the world (Berglund 2007, 79; Lemon and Taylor 1997, 239). Developing this point, Berglund (2007), citing Dreyfus (1991, 32) claims:

the world becomes better known to us as individuals when we look more at more and more aspects of the world and our lives, and try to relate these to each other in an ever more comprehensive structure, (p.79-8).

It follows, therefore, that the researcher's goal is to retain and communicate the essential meaning of the research subject’s experiences (Lemon and Taylor 1997, 237).

\section{Design and conduct of the study}

Seeking a better understanding of graduates' experiences of employment and vocational learning in the workplace, a phenomenological approach was used during a recent study. In order to show how this approach works in practice, it is necessary to look at the way the study was planned and conducted, including the approach used when analysing the data. Specific aims for the study were to explore:

- emerging graduate experiences in the labour market, and perceptions concerning the world of employment, workplace learning, their job prospects and employability;

- how different educational processes -in terms of school, university, teacher, tutor and peer group effect - can impact upon different employment outcomes for graduates; 
- the interplay between a person's career decision making and the context within which they make decisions

The complex nature of this study required a qualitative research strategy and methods of exploring people's perceptions and understandings concerning their employment experiences and the meanings they ascribe to them. Consequently, for this investigation, qualitative data was obtained during email interviews with 35 participants, graduates within the last ten years. All are, or were at some stage during their studies, employed as teaching or higher level teaching assistants in educational establishments. As a group they are highly aspirational and many have gained, or are in the process of studying for, a PGCE qualification.

Ethics approval was sought and obtained from the author's faculty ethics committee when planning this investigation. Prior to the onset of this investigation, the participants were approached via email, inviting them to take part in the investigation. The nature and purpose of the investigation was explained, and, in line with common practice, they were assured their privacy and anonymity would be protected.

A requirement for this type of study is to gather data in such a way that the richness inherent in the participant's experience is recognised and acknowledged. The goal is to uncover the meaningful ways in which things are experienced, made sense of and enacted in everyday life (Berglund 2007, 75-76). From the beginning there was an expectation on my part that each interview would be asynchronous rather than synchronous and that it would quickly become a shared conversation, a collaborative venture, during which the researcher and the research participant would immerse themselves in the emerging conversation and become co-constructors as well as interpreters of knowledge through discourse on line (James and Busher 2009, 25). A collaborative approach within online, as well as off-line, research encourages participants to feel they are core members of the research team.

There are advantages to be had from working in this way. The researcher becomes a participant rather than a detached observer and the texts that are created online reflect and shape the researcher's and the subject's understandings of the situations in which they live and work. On the other hand, adopting this approach can create problems in terms of eliminating researcher subjective attitudes and judgments and when judging the authenticity of the participant's online contributions. Addressing this concern, Hayes (1997) asserts that it is naïve, and impractical, for researchers to claim they have no impact on what they are studying when working in real everyday situations. The natural curiosity of people concerning the researcher, and his, or her, activities causes them to develop their own theories about what is going on, and what lies behind 
the research activity. Furthermore, it is argued that it is both morally and scientifically valid to inform, and involve, subjects of research (Heron 1996; Reason 1994).

When conducting online interviews, it is noticeable how hard the researcher has to work to ensure there is space for the participants' authentic voice to be heard. Inequalities of power in research projects arise from the positioning of participants within them. Initially, the researcher can be expected to take the lead in the types of question asked and the way they are asked. However, when the participant is encouraged and allowed to take control over the direction of the conversation, it can develop in unexpected ways and result in the creation of new understandings on the part of the researcher and the participant. Commenting on this process, James and Busher $(2009,53)$ highlight how 'knowledge and the construction of process, as well as substance, is shaped by the flows of power in social situations.' Furthermore, being responsive to participants, showing one is listening carefully to, and interested in, what she, or he, has to say helps them to believe the researcher is genuinely interested in them (James and Busher 2009, 137). Working hard to develop the research relationship is also recommended as a way of gauging the authenticity of the participant's online contributions (James and Busher 2006).

With these thoughts in mind, the following interview schedule containing open questions was used in ways that allowed each participant to develop at length and in depth their narrative.

1. What does your work involve and how do you see your job developing over the coming twelve months? How do you feel about this?

2. How would you describe relations within teams/groups of which you are a member? Do groups/teams get along with one another? What images would you use to describe and explain these working relationships?

3. How do you and others learn how to do your job? How do you get to know what to do and how to do it?

4. In what ways have your experiences in your everyday working-life shaped your sense of professional identity?

Pleasingly, each interview quickly developed into an online asynchronous conversation during which participants introduced and responded to themes that subsequent questions were intended to uncover. At other times, some of the responses invited one or more follow-up questions.

\section{Analysis}


Accepting Lemon and Taylor's (1997, 236) advice, the first stage of the analysis involved the reading and re-reading of each participant's narrative in order to gain 'a feel for them' and to allow potential meanings to emerge from the data. In many cases when working with rich, qualitative data, statements have multiple meanings, and it is important to capture as many of these as possible. As Lemon and Taylor $(1997,237)$ explain, individual statements can indicate a number of themes, and the frequency with which a theme is mentioned is an indication of its strength. This proved to be the case in this instance. The process is similar to the one used in grounded theory analysis and involves looking for higher and lower order themes that appear to encapsulate people's lived experience of employment and vocational learning. Offered by way of illustration, the ensuing discussion draws on the analysis of one respondent's narrative. To ensure her anonymity, a pseudonym (Sarah) is used when referring, with her permission, to her. The thematic analysis of Sarah's narrative uncovered four main themes which, together, appear to shed light on her lived experience in employment as a teaching assistant (TA) and subsequently a higher level teaching assistant (HLTA) in a primary school.

\section{Lived apprenticeship}

In recent years, workforce modernisation and remodelling have resulted in a massive increase in the number of support staff working in schools, a corresponding weakening of the traditional boundaries that have previously defined the work of teachers and support staff and the creation of new 'associate' professional roles (Edmond and Price 2009, 303). Nowadays, it is commonplace for TAs and HLTAs to undertake both pedagogic and pastoral roles within schools, and, sometimes to lead and manage colleagues as they respond to changes in government policy. When it comes to understanding practitioner perspectives concerning the experience of regularly being given and fulfilling new roles and responsibilities, there is a suggestion in Sarah's account that it can be described as a lived apprenticeship which is negotiated within everyday social settings within the school. Furthermore, the process appears to be full of 'twists and turns':

My learning regarding the HLTA role has mainly been through working in the classroom and observing... I've worked in schools for about 13 years and so in that time I've witnessed a wide variety of teaching styles and personalities. I suppose I've had a rather extended apprenticeship. I've watched, processed and tried out a variety of behaviour and teaching styles that I've seen being used by others. There have been courses that have related to different subjects taught in school. These have been a useful supplement but the actual hands-on experience of standing in front of a class has been a much more powerful learning curve! That moment of realising that you will sink or swim suddenly makes you think on your feet and I don't think any number of courses would prepare you for that.

The growth of my role has been like being caught up in a storm, initially loud and noisy opposition, a few thunder storms and now settling down to more balmy weather- just the occasional thunder cloud on the horizon! 


\title{
Teams and teamwork
}

For Sarah, her lived apprenticeship seems to have been largely negotiating within, and at, the boundaries of everyday working groups, and especially pedagogic teams. Sometimes, when she is left alone to plan and deliver a day's lessons, for example, she appears to engage in a level of 'role self-determination' that reflects her perceptions of the priorities when working with a group of children (Tucker 2009, 294). At other times, her professional learning and development are achieved when working with and alongside teachers and other colleagues. Implicit in this part of her narrative is a suggestion that the quality of her 'apprenticeship' is determined by the way she is treated by others, especially qualified teachers, and the quality of their relationships:

\begin{abstract}
Initially, when I gained HLTA status there were some teaching staff that did not agree with the principle of the role and they made working with them quite difficult. However, other teachers were supportive and encouraging and seemed to be interested in my developing role and skills. Those that had misgivings about my role were gradually won over, apart from one, and she still takes delight in making life difficult.

Considering this aspect of learning - it seems to me that the key factor to learning taking place is the acceptance of the 'non teacher' in the classroom and although we are moving forward with this kind of acceptance, whilst ever there is opposition from teaching staff then real learning doesn't take place for the 'apprentice'. Teachers that have been supportive and willing to let me 'have a go' are the ones that I've learnt so much from. They have allowed me to be in their classroom and see what happens 'warts and all' and that leads me to think that they are the individuals who probably feel most confident in their abilities to teach/survive classroom disasters. They have been happy to laugh alongside me at the mistakes that we both make and we have been able to support each other because we seem to have created our own 'personal work history'.... this has meant that we have become more than just two separate individuals working in the same building- we actually have things in common.

The importance to me of having that good relationship is paramount, it is a way of the teacher showing that they do value and respect the work that you do - perhaps more importantly that you are actually another human being! We have shared experiences that have ranged from those of sheer desperation and exhaustion to delight at conquering difficulties and discovering new skills. Truthfully, without the support of these colleagues/friends it would have been easy to give up.
\end{abstract}

\section{Job demand/job control:}

Sarah's narrative captures the ambivalent feelings which many respondents express concerning their working conditions. On the one hand, the demands placed on them by their jobs are notably demanding. Typically, TAs and HLTAs work across the institution with often the most challenging of children and behaviours; negotiating and renegotiating their own personal and professional identities against a background of changing roles and responsibilities, and, in many cases, fractional contracts and low pay. Frequently, respondents speak of 'being paid a pittance' for often 'doing the work of a teacher,' and express feelings of being 'exploited.' 
If my role is viewed as an apprenticeship it would be welcomed if I had an end goal in sight, for instance if a level of attainment could be agreed and limits imposed on the amount and types of work that I currently deal with. This is one of the most frustrating aspects of my work, the fact that I am expected to swap between teacher and general dogs body at the drop of a hat. The main irritation with this is the fact that it really does make me feel undervalued and not really respected- after all, teachers are not expected to move from year group to year group or be relegated to filing in the space of a working week, yet I am and do. One such example would be when I took on the role of PE coordinator to cover for maternity leave and through much blood, sweat and tears made a really good job of what I did. However, the next school year it was handed to another teacher and I was 'relegated' back to more menial tasks! This is possibly a flaw in the system as it doesn't seem fair to entrust someone with a role (the implication being that you are seen as a capable member of staff) and then at the drop of a hat take it from them (the implication being that you don't really count for much)... it indicates that actually you are more of a disposable resource than a valued staff member.

The disadvantages for me are that I have started to feel used rather than valued - the lack of consideration given to providing lesson plans when I have a class for the whole day now makes me feel that I am just seen as a babysitter - and as long as I keep the class under control then that is all that is wanted from me. This is not how I work- if I'm going to do a job then I like to do it properly- and I feel that the school doesn't realise that this is important to me.

Here one begins to see the impact that working conditions can have on people's emerging personal and professional identities:

I think that my role has evolved quickly and working conditions have not moved at the same pace, to be considered as a true professional it would be good to receive all year round pay (not, term time only) also to have a fixed contract which states clearly my job description- am I non-teaching or teaching assistant? Often I'm not sure and I'm certain that other staff members need to be reminded as the blurring of boundaries can be exasperating...definitely for me, perhaps for them.

I feel more of a professional when I know what my expected role in school is- when I am expected to swap between roles this indicates a lack of respect and a degree of 'being used', almost emphasising the fact that really I am not regarded as a professional...'real professionals' (teachers) are not and would not be asked to be as flexible in their role as I am expected to be in mine.

And yet, in contrast, respondents often speak warmly of the opportunities their jobs present in terms of enabling them to develop personally and professionally. Within the literature, concerns about the relationship between the demands placed on people by their jobs, and the control they have over aspects of their jobs are often considered in terms of their personal well-being. Much of this literature is concerned with the extent to which people with 'high strain jobs' are likely to suffer from mental or physical illness and reduced well-being, and steps that can be taken to reduce the strain effect (Ha“usser et al. 2010). Interestingly, in common with other participant narratives, Sarah's suggests that a possible important, positive factor for them in terms of their welfare is the extent to which in times of rapid change in their roles and responsibilities they have control over aspects of their work and that there are important personal benefits to be had by them when engaging in the work.

I think that I have more control over what I actually deliver in the classroom- this is usually left to my 
discretion- and to date I have not had any complaints about what I have been producing- I am sure that it is a relief for staff not to have to prepare a lesson that they are not going to teach themselves, they are quite happy for me to produce my own plans.

It's true to say that learning for me just happened without me realising it- it's only when I began to think about why I would use/not use certain strategies that I became aware that I was learning and then I became 'hooked' on bettering myself and specifically searching out best practice that I could use.

I am grateful to the Head for giving me so many opportunities to grow and improve in my role but equally I think that I have contributed to improvements that have happened in school so there seems to be a kind of cycle of growth and improvement continually taking place. This period of learning for me has been exciting and challenging and because it, sort of, crept up on me without me knowing it, has taken me by surprise to discover what a fantastic free resource I've had all these years-the opportunities to watch and learn both practical and 'people' skills.

An important feature within the respondent's narratives is the extent to which vocational learning is seen to be opportunistic. Often, it would seem, opportunities for vocational learning arise as part of people's everyday collective work, and when they are required to 'act up' an absent person's role. Commenting on the take up of these opportunities for vocational learning, Johnsson and Boud (2010, 359) assert:

We believe the differences in how workers take up these opportunities result from a complex combination of situational factors that generate invitational patterns signaled from and by various understandings and interactions among actors doing collective work. Rather than a deficit view of learning that needs fixing, an emergent model of learning work suggests that learning develops as a collective generative endeavour from changing patterns of interactional understandings with others.

Attempting to explain apparent differences in people's take up of opportunities for vocational learning in the workplace, it is apparent that, when describing their everyday working experiences and the meanings they ascribe to them, respondents implicitly describe an ongoing process of emergent psychological contracting, operating at all times within their organisational settings. The process is best likened to unscripted drama during which people's expectations of one another regarding feeling safe, being valued as a person and for their work, and being beneficiaries of supported opportunities for personal and professional and career development are affirmed, or breached. When these largely unspoken expectations are affirmed, it is claimed people are likely to engage in collaborative processes of knowledge creation and sharing within and across teams. On the other hand, when expectations are not affirmed, it is suggested people will be less willing to engage in these processes (Leach 2009 \& 2010). 


\section{Moving on}

Reflecting on the contents of Sarah's and other participant narratives, there is a suggestion that 'the school represents a 'site of struggle' wherein identity is not fixed but played out through the dynamics of human relations’ (Tucker 2009, 297, citing Apple 1993, 46). In these personal narratives there is also a clear sense that participants are engaging in a personal journey and a point has been reached where they need to move on.

I've enjoyed my role in school but feel that probably it has hit a ceiling in that there is not much more scope left for progression- being a professional indicates to me that there is always room for development both personally and for the particular role held- at the present time I cannot see how the job I have now will be able to continue to grow- the next step forward is to actually become a teacher. I know over the past few years that I have saved the school a fortune in supply cover fees- this suits me though as I am moving on to teacher training in September and I have viewed the experiences as a way of developing my class room skills.

I am very sad to be leaving but need to move on. I need to be looked upon as someone different. I consider my job is worth much more than 22 hours.

\section{Discussion and conclusions}

As indicated in the introduction, this study is part of a wider investigation which seeks to explore ways of conceptualising the individual-organisation bond in ways which generate new opportunities for conducting research into matters concerning graduate vocational learning, employment and employability. Participants in this study work, or, at the time, did work in schools. The importance of this group lies in their potential contribution to wider, international discussions surrounding the changing employment landscape in both public and private organisations, and the nature of lifelong, vocational learning during times of rapid and continuous change. Their narratives support Apple’s (1993) contention that schools and other types of organisation represent the 'site of struggle' wherein identity is not just fixed but played out through the dynamics of human relations within the working group.

Nowadays, it is commonplace for theorists and practitioners alike to claim that an organisation's greatest resource is its people and their capacity to learn. The organisation's future, it is suggested, is dependent on its willingness to nurture, build on and tap into people's commitment and capacity to learn at all organisational levels and to embrace change (Senge 1990). However, employee resistance to change has long been an issue of research interest, and a concern for leaders and managers (King and Anderson, 2002, 195). 
The context of the respondent's narratives is located within wider workforce reform issues for school and other public sector organisations, and the corresponding changes in paraprofessional roles and responsibilities. It is apparent from the analysis that, when describing their everyday working experiences and the meanings they ascribe to them, respondents are implicitly describing the processes of emergent psychological contracting, operating at all times within teams and across their organisations. The process is best likened to unscripted drama during which people's expectations of one another regarding feeling safe, being valued as a person and for their work, and being beneficiaries of job opportunities through which they can develop personally and professionally are affirmed, or breached. Equally revealing in individual stories is the extent to which work during turbulent times is portrayed as an ongoing 'lived apprenticeship.' Their stories also highlight the importance of being allowed a measure of control over aspects of their work as opposed to being 'micro-managed' during times of 'high strain' change. Well-managed change can produce a workforce that is committed, enthusiastic and ready to deal with the challenges and stresses of demanding working practices. Badly managed change, however, has a graver psychological impact, producing staff who feel betrayed or mismanaged or who are operating under unnecessarily stressful conditions (West and Wallace 1991; West and Anderson 1992). This in turn leads to problems with staff retention, apathy, burnout and, in some cases, even malpractice. Consequently, it is apparent that, when planning, leading and managing interventions to encourage vocational learning in the workplace, successful outcomes are more likely when leaders and managers have an informed appreciation of the dynamics of human relations within the working group and across the organisation.

When selecting a methodology and methods for a particular piece of research the issue is not whether they are right or wrong but rather whether, or not, they fit the aims of the investigation. For this study, a phenomenological approach was used because it is seen to be a structured way of investigating issues surrounding vocational learning, employment and employability as they are experienced, given meaning and translated into action by employees. According to Berglund (2007, 89):

Phenomenological methods are especially well suited for investigating the gaps between real-life occurrences and the theoretical concepts on the one hand and individuals' interpretations of these occurrences or concepts on the other.

The phenomenological approach thus provides a philosophy of vocational learning, employment and employability, and also a procedure for documenting and describing the lived experiences of employees. The use of quantitative methods with their requirement to control, manipulate and 
measure, may be considered necessary when the object of the study is to uncover ways of managing and controlling the processes whereby people may 'become employable'. On the other hand, methodologies which ignore and therefore fail to account for people's subjective and intuitive understandings concerning the nature of employment, vocational learning and the condition of 'being employable' can produce information which is misleading. To ignore the subjective and intuitive side of people's live experiences is likely to lead to research which gives a partial and distorted view of the phenomena.

\section{References}

Apple, M. 1993. What post-modernists forget: cultural capital and official knowledge, Curriculum Studies 1, no. 3: $12-21$.

Berger, P. and Luckmann, T. 1966. The Social Construction of Reality: A treatise in the sociology of knowledge. New York: Doubleday.

Berglund , H. 2007 Researching entrepreneurship as live experience. In Handbook of Qualitative Research Methods in Entrepreneurship, ed. H. Neergaard and J.P. Ulhoi, 75-93, Cheltenham: Edward Elgar Publishing Ltd.

Berner, B. 2010. Crossing boundaries and maintaining differences between school and industry: forms of boundary- work in Swedish vocational education. Journal of Education and Work 23, no. 1: 27-42.

BIS: Department for Business, Innovation and Skills. Skills for Growth: The national Skills Strategy. November 2009a.

BIS: Department for Business, Innovation and Skills. Higher Ambitions: the future of universities in a knowledge economy. November 2009b.

Boeren, E., Nicaise, I. and Baert, H. 2010. Theoretical models of participation in adult education: the need for an integrated model, International Journal of Lifelong Education 29, no. 1: 45-61.

Brooks, R. and Everett, G. 2008. The impact of higher education on lifelong learning, International Journal of Lifelong Education 27, no. 3: 239-54.

Centeno, V. 2011. Lifelong Learning: a policy concept with a long past but a short history, International Journal of Lifelong Education 30, no. 2: 133-50.

Clarke, M. and Patrickson, M. 2008. The new covenant of employability, Employee Relations 30, no. 2: 121-41.

Denscombe, M. 2007. The Good Research Guide for small-scale social research projects. Maidenhead: Open University Press.

Dreyfus, H. 1991. Being-in-the-World: A commentary on Heidegger's being and time, division 1. Cambridge, MA: MIT Press.

Edley, N. 2001. Unravelling Social Constructionism. Theory \& Psychology 11, no. 3: 433-41.

Edmond, N. and Price, M. 2009. Workforce remodelling and pastoral care in schools: a diversification of roles or a de-professionalisation of functions? Pastoral Care in Education 27, no. 4: 301-11.

Edwards, A, Lunt, I. and Stamou, E. 2010. Inter-professional work and expertise: new roles at the boundaries of schools. British Educational Research Journal 36, no.1: 27-45.

Fox, S. 1997. From Management Education and Development to the Study of Management Learning. In Management Learning: Integrating Perspectives in Theory and Practice, ed. J. Burgoyne, \& B. Reynolds, 2137, London: Sage.

Gergen, K.J. 2001a. Social Construction in Context. London: Sage.

Gergen, K. J. 2001b. Construction in Contention: Towards Consequential Resolutions. Theory \& Psychology 11, no. 3: 419-32. 
Guile, D. 2009. Conceptualising the transition from education to work as vocational practice: lessons from the UK's creative and cultural sector. British Educational Research Journal 35, no. 5:761-79.

Hayes, J. 2007. The theory and practice of change management ( $2^{\text {nd }}$ edition). Basingstoke: Palgrave Macmillan.

Hayes, N. 1998a. Psychological processes in organisational cultures 1: social representations and organisational semiotics. Human Systems: The Journal of Systematic Consultation \& Management 9, no. 3/4: 59-65.

Hayes, N. 1998b. Psychological processes in organisational cultures 11: social identification and organisational groups. Human Systems: The Journal of Systematic Consultation \& Management 9, no. 3/4: 17-21.

Hayes, N. J. 1997. Doing qualitative analysis in psychology. Hove: Psychological Press.

Hayes, N. 2000. Doing psychological research: gathering and analysing data. Buckingham/Philadelphia: Open University Press.

Heidegger, M. 1962. Being and Time. New York: Harper and Row.

Heron, J. 1996. Co-operative Inquiry: Research into the Human Condition. London: Sage.

Hodkinson, P. 2005. Reconceptualising the relations between college-based and workplace learning. Journal of Workplace Learning 17, no. 8: 521-32.

Holden, R. and Hamblett, J. 2007. The transition from higher education into work: tales of cohesion and fragmentation. Education \& Training 49, no. 7: 516-85.

Häusser, J.A., Mojzisch, A., Niesel, M. and Schulz-Hardt, S. 2010. Ten years on: A review of recent research on the Job-Demand-Control (Support) model and psychological well-being. Work \& Stress 24, no. 1: 1-35.

Husserl, E. 1931. Ideas: General Introduction to Pure Phenomenology. London: George Allen and Unwin.

Husserl, E. 1982. Ideas Pertaining to a Pure Phenomenology and to a Phenomenological Philosophy ( $1^{\text {st }}$ book). General Introduction to a Pure Phenomenology, trans, by F. Kersten. The Hague: Martinus Nijhoff.

James, N. and Busher, H. 2006. Credibility, authenticity and voice: dilemmas in web-based interviewing. Qualitative Research Journal 6, no. 3: 403-20.

James, N. and Busher, H. 2009. Online Interviewing. London: Sage.

Johnsson, M.C. and Boud, D. Towards an emergent view of learning work. International Journal of Lifelong Education 29, no. 2: 359-72.

Kanter, R.M. 1996. Beyond the cowboy and the corpocrat. In How organisations Learn, ed. K. Starkey, 43-59. London: International Thomson Business Press.

Kazenbach, J.R. and Smith, D.K. 1993. The Wisdom of Teams: Creating the High-performance Organization. Harvard Business School Press: Boston, Mass.

King, N. and Anderson, N. 2002. Managing innovation and change: a critical guide for organisations ( $2^{\text {nd }}$ edition). London: Thomson Learning.

Lave, J. and Wenger, E. 1991. Situated Learning: Legitimate Peripheral Participation. Cambridge University Press.

Leach, T. 2009. Maybe I can fly: Nurturing personal and collective learning in professional learning communities. Pastoral Care in Education 27, no. 4: 313-23

Leach, T. 2010. Knowledge creation and deployment in the small, but growing, enterprise and the psychological contract. Research in Post-Compulsory Education 15, no. 3: 329-44

Lemon, N. and Taylor, H. 1997 Caring in casualty: the phenomenology of nursing care. In: Doing qualitative analysis in psychology, ed. N.J. Hayes, 227-43. Hove: Psychological Press.

Lindeman, E. 1926 The Meaning of Adult Education, New York: New Republic.

Nixon, I., Smith. K., Stafford, R. and Camm. S. 2006. Work-based learning: illuminating the higher education landscape, final report. The Higher Education Academy.

Reason, P. ed.1994. Participation in Human Inquiry. London: Sage.

Senge, P.M. 1990. The fifth dimension: the art and practice of the learning organisation. London: Century Business.

Starkey, K. ed.1996. How organisations learn. London: International Thomson Business Press. 
Stata, R. 1996. Organisational Learning: the key to management innovation. In How organisations learn, ed. K. Starkey 316-334. London: International Thomson Business Press.

Stoll, L. and K. Seashore. 2007. Professional learning communities: Elaborating new approaches. In Professional learning communities: Divergence, depth and dilemmas, ed. L. Stoll and K. Seashore. 1-13. Maidenhead: McGraw-Hill/Open University Press.

Tucker, S. 2009. Perceptions and reflections on the role of the teaching assistant in the classroom environment, Pastoral Care in Education 27, no.4: 291-300.

Wenger, E. 1998. Communities of Practice: Learning, Meaning, and Identity. Cambridge: Cambridge University Press.

Wenger, E., White, N. and Smith, J.D. 2009. Digital Habitats: stewarding technology for communities. Portland, Or: CPSquare.

West, M.A. and N.R. Anderson. 1992. Innovation, cultural values, and the management of change in British hospitals. Work and Stress 6: 293-310

West, M.A. and Wallace, M. 1991. Innovation in health care teams. European Journal of Social Psychology 21: 303-15 